Volume 66

Issue 5 Symposia

Article 6

$2-7-2022$

\title{
Giving Voice to Values: How To Speak Your Mind When You Know What's Right
}

Mary C. Gentile

Follow this and additional works at: https://digitalcommons.law.villanova.edu/vlr

Part of the Legal Ethics and Professional Responsibility Commons

\section{Recommended Citation}

Mary C. Gentile, Giving Voice to Values: How To Speak Your Mind When You Know What's Right, 66 Vill. L. Rev. 915 (2022).

Available at: https://digitalcommons.law.villanova.edu/vlr/vol66/iss5/6

This Symposia is brought to you for free and open access by the Journals at Villanova University Charles Widger School of Law Digital Repository. It has been accepted for inclusion in Villanova Law Review by an authorized editor of Villanova University Charles Widger School of Law Digital Repository. 
TRANSCRIPTION OF THE 2021 VILLANOVA LAW REVIEW

NORMAN J. SHACHOY SYMPOSIUM: PRACTICAL ETHICS IN CORPORATE LAW: THE SCIENCE, INSTRUCTION AND "REAL-WORLD" APPLICATION

\author{
Featured Speaker: Giving Voice to Values: How to Speak Your Mind \\ When You KnOW What's Right* \\ Presented By: Mary C. Gentile**
}

Professor Mary C. Gentile, University of Virginia Darden School of Business: Good morning. I'm really happy to be joining you today at the Villanova Law Review Symposium on practical ethics in corporate law. What I'd like to do today is to spend a little bit of time explaining to you what Giving Voice to Values-or GVV, as I refer to it-is and how it can be useful for lawyers in a corporate context.

So, to begin, Giving Voice to Values is an innovative approach to values-driven leadership development. I actually created it for use in MBA graduate business education, which is where I spent the majority of my professional career. I spent ten years at Harvard Business School where I helped to develop their first required curriculum on ethics and values and leadership and decision making. Now I'm based at the University of Virginia Darden School of Business and I created Giving Voice to Values primarily because I was frustrated and disillusioned with the way we talked about ethics in a corporate context. I'm going to talk to you about the source of that frustration; what Giving Voice to Values is and how it addresses that frustration; the research and the foundations for Giving Voice to Values; and then maybe at the end if we have time, I'll suggest a few things about the implications of GVV for lawyers in a corporate context.

What I'll say just at the beginning about that though, is that law is a business and Giving Voice to Values is about enabling people to more effectively, more confidently, more naturally, and hopefully more successfully, voice and enact their values in an organizational context. Many of the ethical issues you will address in your careers will be less about the nuances of legal ethics-those will come up, but you know those are the kinds of things that you are studying and spending a good bit of time on in law schools: understanding the implications, the limits of the law, and

* The 2021 Norman J. Shachoy Symposium took place virtually on February 19, 2021 at Villanova University Charles Widger School of Law. This transcript has been edited.

** PhD, Creator/Director of Giving Voice to Values, Richard M. Waitzer Bicentennial Professor of Ethics at the University of Virginia Darden School of Business and Author, Giving Voice to Values: How to Speak Your Mind When You Know What's Right. 
what the law allows. But what Giving Voice to Values is about is actually helping you deal with some of the corporate and organizational pressures you are likely to encounter-the pressures that you might encounter precisely because you're operating in a business and in a corporate law context.

As I mentioned, GVV grew out of my own frustration with the ways we taught ethics in professional education settings. I felt that our approach was too often futile and sometimes even hypocritical. And I felt this way because we approached ethics as if it was entirely a cognitive issue, as if it was entirely about giving you some intellectual framework, some black box analysis, where you would put the data in one side, and then the ethical answer would come out the other end and then we were done, right? And in the box there might be philosophy, there might be law, there may be regulatory constraints, et cetera. I call this the "Preach and Pretend" method because we would preach to you about how to figure out what the right thing to do is. And then we would pretend that you will know how to get it done. This seemed inadequate, especially if you might be operating in a context where the pressures were pushing against your acting on those values-based positions. So out of my frustration, I took a step back from this work. This was perhaps about ten to twelve years ago, and around that time I had a number of experiences that led me to think of a new way of approaching professional ethics education and I also began to see some new research starting to emerge. I'm not going to share all the stories with you because we don't have the time for that, but let me just say briefly what we were learning from the research about how to prepare people to be impactful around values-based positions.

So, there was a lot of research coming out in the field of psychology. There was research around habit formation-you may have seen some of this work. For example, there was Charles Duhigg's book on The Power of Habit. There is also a field of research in psychology called the study of positive deviance-and these are folks who study individuals who deviate from the norm, but in a positive direction. The folks who do that research have a nice phrase-it's their phrase, not mine-they say, "If you want to have an impact on people's behavior, rather than asking them to think their way into a different way of acting, it's more impactful to ask them to act their way into a different way of thinking." So, I thought, well, that's kind of interesting. Then there was increasing research in the field of cognitive neuroscience-you've probably seen some of the popularization of this work. For example, there is research around the concept of brain plasticity-the idea that our brains can grow and develop and changeand there is research on the creation of new neural pathways through repetition of certain kinds of behaviors. But the research I'm going to mention to you comes from the field of kinesthetic, or the study of physical movement, because I think it makes the idea behind Giving Voice to Values more tangible and easier to understand and remember. 
Back in the day, when I was working at Harvard Business School, I decided I needed to take a self-defense class. I looked around Boston and there were a lot of these classes and most of them just taught you the physical moves of self-defense-fist to bridge of nose or heel to instep or knee to groin-and you'd practice these moves in the air. The idea behind this approach was the assumption that once I knew these moves, if anyone ever attacked me, I would know what to do.

But, there was one class that was different. It was called "Model Mugging" and it was a developmental approach, so they would teach you all those physical moves and you would practice them in the air. However, once you knew the moves, they'd bring in a gentleman in a padded suit sort of like the Michelin Man. And he would try to attack us so we could use these moves on him-full force-because he was protected. And in the beginning, it was a little ludicrous because you just stood there in line waiting your turn to get attacked, right? But as the class went on, week after week, I might be talking to someone over here, he would come and grab me of from another direction. I would never know when. I'd never know what hold he was going to use. It was really nerve wracking, but the idea was that we could then practice our defensive moves in the same kind of cognitive and emotional and physiological state that we would be in when we needed to use them. This approach was based on research on what's called "specific state muscle memory." Those of you who are athletes will be familiar with this; it's the idea that you rehearse your actions in the same cognitive and physiological and emotional states that you will be in when you need to use them. You rehearse something in those same states so that, when you're in the actual situation, even if you freeze, your body will just automatically remember. So the tennis pro will practice her serve over and over before she goes to tournament so that when she's there under all that stress her body just naturally assumes the proper form.

So I was thinking one day in that class, could we create a kind of moral muscle memory, you know? Could we create a default behavior or default to voice, but not just to speaking up? You know, they talk a lot these days about speak-up cultures; this is not just about speaking up, you know, speaking truth to power, it's actually about informed voice. Because one of the things that I was learning from talking to many, many people and collecting many, many stories of people who encountered values conflicts was that often when people were effective at dealing with these, it was less a matter of you know, blowing a whistle, which is often very costly and difficult. It was less a matter of, you know, shaking their fist and speaking truth to power. It was often more strategic. It was more tactical. They would use the same skills for communications and influence and negotiations and problem definition and reframing that you are already learning to use, especially as lawyers. They would use those same skills to promote a values-driven position. 
Sometimes, it seems that when we encounter values conflicts, we sort of dumb ourselves down. We suddenly think, "Oh, this is a defining moment, a test of moral character, I need to fall on my sword, you know." Actually, what I was finding is that people who are most effective at this were actually being able to tap into those skills that they already had. The idea was: can we can we rehearse this? Can we create a kind of, as I said before, a moral muscle memory? A default to informed voice? So, that was the idea behind Giving Voice to Values. So then I thought, well, what do we do when we try and teach about ethics, whether it's in business school or a law school or medical school or the U.S. military or any of the many corporations where we teach and train about ethics. And then I became discouraged again, because we tend to approach these issues by sharing the relevant laws and regulations and company codes of conduct-and in your case, the standards of professional ethics for the legal profession-and then we would give people scenarios and we'd say, "What should you do?" You would be asked to analyze the situation to decide if it was "over the line or not." In other words, instead of identifying and practicing effectives scripts and action plans for acting on our values, we focused almost exclusively on simply deciding what our values should be in a particular situation-and we would stop there. It's that "Preach and Pretend" method again.

But I decided that's really not what we want to do because what we were learning again from the research and psychology is that when people encounter values conflicts, they typically do not sit down and make the pro and con list. They don't sit down and think about, "What would Aristotle say?" or, "What would the code of legal ethics say?" We tend to react emotionally, automatically-even sometimes unconsciously-in the moment, based on what feels feasible and then we rationalize after the fact, post hoc, why it was the right thing to do, or maybe even why it was the only thing to do. This is natural; it's not intentional; it's because of this automatic desire not to live in that place of cognitive dissonance where you know something's wrong and you do it anyway. It's a sort of self-protective measure that we engage in. And so, if we simply teach people to do ethical analysis-that black box I was talking about earlier-you're not actually superseding that automatic reaction. So what I thought we really need is to develop a new pedagogical method, a teaching technology that will enable us to literally rewire that automatic connection. What I wanted to do was to give people the opportunity to rehearse, to practice, to pre-script, to develop that habit, that moral muscle memory in a kind of safe space, a sort of learning laboratory.

So we created what we call the "Giving Voice to Values Thought Experiment." Instead of giving you a scenario or case study and asking, "What should you do?," we will give you a scenario where the protagonist has already decided what he or she thinks the right thing to do is. And the question for the learner is, "How can that protagonist get the right thing done effectively?" So, we're actually engaging you in that process of creat- 
ing scripts and action plans and rehearsing them; practicing them and creating that habit; and engaging in peer coaching to advise each other and to try and improve and enhance your scripts and action plans. So it's a process, an iterative process of literally rewiring our automatic response to values conflicts. And we know from the research on creativity and innovation that people tend to be more creative and innovative when they feel as if they have that safe space, that laboratory, to engage in this kind of problem solving and rehearsal. So, that was the idea behind Giving Voice to Values. It is pretty simple actually, it's just a reframing: instead of focusing on asking, "What is the right thing to do?," we focus on asking and answering, "Once you know what you think is right, how can you get it done effectively?"

The interesting thing is that when we started creating teaching materials-hundreds of cases all based on real situations as well as exercises and readings and books and online modules-and making them available, the pickup has been much more extensive and much more rapid than we could have anticipated. GVV has now been shared and/or used on all seven continents, including the Antarctic. It's been translated into different languages. Obviously it's been used in business schools, but there are applications in the legal context, in an engineering context, healthcare context. As I mentioned, we have worked with the U.S. military, with major corporations, with NGOs, and so on. The focus on action and the focus on actually enabling people to feel empowered to act on their values has been quite attractive. I think the idea of framing ethics as if it's "thou shalt not"-as if it's a constraint on action-is not always that attractive, particularly to people who have professional aspirations, who have ambition. So, Giving Voice to Values reverses that and frames values-driven action and values-driven leadership as all about "can do," as about getting something done, as about acting in a way that is consistent with who I am and who I want to be. So as I said, GVV is really just a reframe and so I'm going to conclude by explaining that Giving Voice to Values is based on three such reframes, or three flips.

We've reversed what it is we're talking about when we talk about ethics in organizational context; we've reversed who it is we think we're talking to; and we've reversed how we're having that conversation. So, in terms of what it is we're talking about, you know, usually people will say, if you want to talk about ethics, don't bother to focus on the so-called clear-cut, black and white, right-wrong kinds of questions; those are easy. It's more impactful to focus on the gray issues, the more complicated ones. And I used to think "Yes, that makes sense," but I've actually changed my mind. Of course, there are a lot of gray issues and I don't know what the right answer is to answer all of those questions, but those are questions where intelligent people of goodwill can legitimately disagree-that's why they're gray, right? But there are a lot of issues where most of us, not everybody, but most of us would agree, "That's clearly over the line, that's clearly illegal, it's clearly fraudulent, it's clearly abusive." But just because most of 
us may feel that way, it doesn't mean we feel that it's actually possible to act effectively in our organizational and corporate context when we're feeling pressure to go in another direction, especially when we're earlier in our careers and we don't feel like we have the authority or the legitimacy yet or the track record.

And so the idea here is that we're going to focus on those more clearcut issues; the issues where most of us would probably agree about what is "right or ethical" because by doing that we can actually get to the conversation about action and scripting and rehearsal. On the other hand, if we focus on the gray issues, we never get past the conversation about how many angels dance on the head of a pin-it will be this endless kind of debate. And so what we really want to do is to have that post-decision-making scenario, the thought experiment, where the protagonist already knows what's right and we're focusing on how to get it done and rehearsing that. Our theory is that if we get better at talking about the so-called clear-cut issues, we will likely get better at talking about the gray issues as well. And also, there's a tendency-as we explained given when we mentioned the research earlier-there's a tendency to see issues as gray even when they are more clear-cut because we don't think it's necessarily possible to do anything else, so it's again an unconscious sort of self-protective measure to avoid seeing the issue as clearly unethical.

The second Giving Voice to Values re-frame or flip is about who we think we're talking to. With GVV, we think of the organization as a bell curve, and this is based on some research by Greg Dees and Peter Crampton on ethics and negotiation. So we think of the organization as a bell curve and we premise that at one tail end of the bell curve are the folks who would self-identify as opportunists, as people who would say, "I'll do whatever it takes to maximize my self-interest, regardless of values." Now, nobody falls into one of these categories all the time, but these are people who say, "That's my primary motivation." And at the other tail end of the bell curve are the folks who would self-identify as idealists, and these are the people who would say, "I will always try and act on my values, regardless of the impact on my self-interest." What we premise is that the majority of us fall under the bell and we call them pragmatists, and I put myself there. And we define pragmatists as people who would say, "I would like to act on my values as long as it doesn't put me at a systematic disadvantage." Now that's not the same as saying, "As long as I know, I will succeed;" it's not the same as saying, "As long as I know, I'll never pay a price;" it simply means, "I think I have a shot."

Now, if you think of your audience this way, I don't think I have the power to change the opportunists; I think they'll always be with us. And I'm not so worried about the idealists, except I would like them to be more skillful, more competent. But we're really focusing on the pragmatists and we're trying to give them the literal scripts and the action plans and the positive examples and the rehearsal, the practice, the peer coaching, the 
opportunity to develop that moral muscle memory to enable them to act in a way that they want to act at their best. We're not trying to change them; we're trying to enable them to act as they already want to act at their best. And our premise is that if enough of the pragmatist and the idealists get better at this-more skillful and more comfortable and more natural at doing this-it changes the water that the opportunities are swimming in, so the calculus that they do to determine what is in their own selfinterest is going to have to shift because they can't rely on the same levels of silent complicity among everyone else.

The final re-frame or GVV flip is how we have this conversation, how we develop this capacity. And I've already explained that to you. We do that through asking a new question; instead of asking, "What's right?," we asked people, "How do you get the right thing done?" Then we give them the opportunity to pre-script and rehearse.

Now, I mentioned that if we had time I might mention a few of the kinds of tools or insights that we've developed for trying to help people develop that capacity to figure out how to get the right thing done, so I'm just going to name a few of them really briefly and you can certainly visit the website-www.givingvoicetovalues.org-or look at the book or any of the many videos or contact me and I'd be happy to share some more ideas with you.

But there are seven pillars of Giving Voice to Values-I'm not going to go through all of them right now, but one of the most powerful ones is the concept of self-knowledge and alignment. So, as you enter your corporate law career, one of the things to think about is, "How am I most effective? How have I been able to successfully persuade others, convince others, influence others around anything-not just ethics-in the past?" The objective is to identify your best skills and also your own natural tendencies, your comfort level: are you introverted or extroverted? Do you prefer to communicate in writing or verbally? Do you like to argue like some lawyers do? Or are you somebody who's more interested in being in a learning conversation where you ask questions and draw insights out of them-which might be the case if you were going into certain fields of law. Think about what your skills are, how you've been effective in the past, and then try to frame the values conflicts you may encounter in a way that will play to your strengths.

I used to think you had to be extroverted, you had to be aggressive, you had to be kind of a risk taker to raise values issues, and what I learned from gathering stories is that, sure, some people who acted on their values effectively fit all of those characteristics, but there were other people who were more risk averse, who were more introverted, who also were able to act on their values effectively. But they framed the challenge very differently. Instead of framing acting ethically as demanding great moral courage, they framed it as the safer route. Instead of trying to communicate by means of debate or an intense and combative conversation with someone, 
they did a written memo where they laid out all the data and made a very serious argument. Or maybe they talked to someone who would talk to someone who had the ear of the decision maker. Maybe they built a set of allies, a kind of coalition. So, in other words, focus on understanding what your strengths are and then framing the value challenges you face in a way that will play to your strengths.

Another one of the pillars of Giving Voice to Values is normalization, understanding that values conflicts are normal; they're going to happen all the time in in our organizational lives and in our personal lives. When we think of values conflicts as exceptional, they can feel like the proverbial "deer-in-headlights" moment. There can be a tendency to just try and squeeze your eyes shut and do what's easiest to get through it so you can get past that and get back to work. But if you actually understand that values conflicts are part of life and are part of business, they're part of law, you can begin to normalize the experience in order to bring the emotion down and allow you to tap into more of those skills and abilities that you already have rather than seeing the ethical conflict as that once in a lifetime defining moment kind of challenge. Staying calm enables you to be more skillful, to see more options, to feel less stress and be more creative in finding ethical solutions.

There are many other tools for voicing and acting effectively on your values - we call them levers and enablers-and we talk about them in the Giving Voice to Values' curriculum. But today there are two things that that I would hope you would remember from this conversation. The first is to remember that at the heart of Giving Voice to Values is this idea that you have more choices than you may think you do; to understand that values conflicts do not mean that you just have to do comply with the unethical pressure or you will never be able to maintain your job or be successful or have whatever you're trying to accomplish. That's what I learned from interviews. It seemed that there were people who would encounter very similar situations and that some of them would find ways to effectively act on their values while there were others who may have wanted to act ethically but just didn't believe they had that option. It wasn't that one group was better or more moral, it's that they actually believed they had more efficacy, that they had more options, more choices.

The second thing I hope you remember is the usefulness of what I call the "GVV Thought Experiment." That is, when you encounter a values conflict, rather than focusing only on figuring out what the right thing to do may be-obviously, you need to decide that-but then think about, "What if I wanted to act on my values-how could I get it done effectively?" That is, bring the emotion down, find some allies, brainstorm, prescript, try to anticipate the kinds of objections you're going to encounter and how you might respond to them. In GVV parlance, we call these objections "reasons and rationalizations." We've identified four of them that 
you hear most frequently-things like, "It's standard operating procedure," or "It's not a big enough deal to worry about," or "It's not my responsibility," or "Yeah, it might be wrong, but I feel loyal to my boss, my colleague, my client." These are very commonly heard rationalizations. They're powerful but they're not bulletproof and we've actually identified lots of ways to begin to counter and respond to them, put these rationalizations into play, so that you can keep a conversation going. And again, we write about those in the materials.

I'm happy to talk to anyone who wants to contact me about how you might begin to respond to some of those but the trick is to anticipate and rehearse so that raising questions and responding to such pressures come more naturally—so you don't freeze in that moment.

So again, now that you have heard a bit about Giving Voice To Values, I hope you'll feel that you have more choices than you thought you did. And I hope you will use the "Giving Voice to Values Thought Experiment" to ask yourself, "What if I know what's right and want to get it done, how can I do so effectively?"- and then pre-script and rehearse such action plans. I hope those are some useful ideas for you. It was a pleasure to be able to share some of Giving Voice to Values with you today, and I hope you enjoy the rest of the Symposium. Thank you for opportunity. 